\title{
ENTREPRENEURSHIP AND THE BUSINESS CYCLE
}

\author{
Philipp D. Koellinger and A. Roy Thurik*
}

Abstract-We find new empirical regularities in the business cycle in a cross-country panel of 22 OECD countries for the period 1972 to 2007; entrepreneurship Granger-causes the cycles of the world economy. Furthermore, the entrepreneurial cycle is positively affected by the national unemployment cycle. We discuss possible causes and implications of these findings.

\section{Introduction}

$\mathrm{D}$ ESPITE the structural changes in modern economies that have led to the increasing importance of entrepreneurs (Audretsch \& Thurik, 2001; Baumol, 2002; Audretsch, 2007), macroeconomic models of business cycles usually abstract from entrepreneurship, with only a few exceptions (Bernanke \& Gertler, 1989; Carlstrom \& Fuerst, 1997; Rampini, 2004). In addition, there is very little empirical evidence on this topic. ${ }^{1}$ Therefore, in establishing the relationship between entrepreneurship and the business cycle, we find it worthwhile to "let the data speak freely" (Hoover, Johansen, \& Juselius, 2008; Juselius, 2009) instead of deducing and calibrating a model from more or less arbitrary assumptions regarding entrepreneurial behavior.

We explore the relationship between entrepreneurship and the business cycle using panel data from 22 OECD countries for the period 1972 to $2007 .^{2}$ To the best of our knowledge, this is the first study of its kind. We differentiate between the aggregate and the national level. The aggregate level refers to the weighted average of business cycle fluctuations across countries. We loosely refer to the aggregate-level business cycle as the global or world economy. ${ }^{3}$ The national level analyzes the data for each of the 22 countries separately and in a panel framework.

Received for publication September 29, 2009. Revision accepted for publication April 26, 2011.

* Both authors: Erasmus University, Tinbergen Institute, Erasmus Research Institute in Management, German Institute for Economic Research, and EIM Business and Policy Research.

We are grateful for comments from Boyan Jovanovic, Adriano Rampini, Dennis Fok, Wim Naude, Erik Canton, Marcus Dejardin, André van Stel, Dick van Dijk, Michael Fritsch, Maurice Bun, Sander Wennekers, Joao Faria, Christian Roessler, Avichai Snir, Schizas Emmanouil, Martin Carree, Niels Bosma, Philip-Hans Franses, two anonymous referees, and participants at various conferences, workshops and seminars. This paper has been written in cooperation with the research program SCALES, carried out by EIM, and financed by the Dutch Ministry of Economic Affairs.

${ }^{1}$ The only other empirical contributions on the topic that we are aware of are the work of Congregado, Glope, and parker (2009) and Golpe (2009). In contrast to this paper, these authors used only self-employment data as a measure of entrepreneurial activity from a smaller number of countries covering a shorter time frame. Also, the focus of their analysis is different from ours, for example, they focus on hysteresis effects and cross-country heterogeneity. Faria et al. $(2009 ; 2010)$ focus on technical aspects of the dynamics and cyclicality of the relationship between unemployment and entrepreneurship.

${ }^{2}$ Entrepreneurship is defined in terms of owner-managers of firms.

${ }^{3}$ The 22 OECD countries account for more than $55 \%$ of the world GDP in all years included in our analysis (OECD, 2010).
Differentiating between these two research levels of the relationship between the entrepreneurship and the business cycle, we obtain four results. First, global fluctuations in entrepreneurship are an early indicator of the world business cycle: they Granger-cause increases in GDP. Second, on this aggregate level, GDP and unemployment cycles do not predict the entrepreneurial cycle. This suggests that other factors besides the world business climate influence global trends in entrepreneurial activity. Third, at the national level, the impact of entrepreneurship on the cycle seems to be weaker than at the aggregate level. Fourth, again at the national level, an upswing in the unemployment cycle leads to a subsequent upswing in the entrepreneurship cycle. Numerous tests using various methods and different data confirm the robustness of these main results. Taken together, our results suggest that entrepreneurship is intertwined with business cycle dynamics in ways that do not follow from existing theories.

In the following section, we discuss related literature. Section III presents our empirical evidence, including a robustness check using another data set. Section IV discusses the empirical finding and concludes. The appendix in Koellinger and Thurik (2009), updated in March 2011, reports on various robustness checks using our main data set.

\section{Related literature}

Bernanke and Gertler (1989) study the influence of entrepreneurs' net worth on borrowing conditions and the resulting investment fluctuations in a neoclassical model of the business cycle. The key to their analysis is the principalagent problem between entrepreneurs and lenders: only entrepreneurs can costlessly observe the returns on their individual projects, whereas outside lenders must jointly incur fixed costs to observe these returns. The greater the collateralizable net worth of the entrepreneur's balance sheet, the lower the expected agency costs will be, as implied by the optimal financial contract. Because entrepreneurs' net worth is likely to be procyclical (i.e., entrepreneurs are more solvent during good times), there will be a decline in agency costs and an increase in real investments during booms. The opposite happens during recessions. Hence, an accelerator effect emerges due to the principalagent problem between entrepreneurs and lenders. The focus of Bernanke and Gertler (1989) is on the real effects caused by random fluctuations in balance sheets (e.g., due to an unanticipated fall in real estate prices), not on entrepreneurship per se. They assume that the potential share of entrepreneurs in the economy is independent of business cycle fluctuations, whereas the fraction of entrepreneurs who get funding and produce is procyclical.

Carlstrom and Fuerst (1997) extend the work of Bernanke and Gertler (1989) by developing a computable gen- 
eral equilibrium model that can quantitatively capture the propagation of productivity shocks through agency costs. Similar to that of Bernanke and Gertler, the model by Carlstrom and Fuerst also does not focus on entrepreneurship per se and assumes that the potential share of entrepreneurs in a population is a constant that does not fluctuate with the cycle. However, due to simplifying assumptions, they end up with the somewhat counterintuitive result that bankruptcy rates and risk premiums are highest during boom periods as a result of positive technology shocks and higher capital prices. Hence, the number of solvent entrepreneurs would then be countercyclical. Furthermore, the bankruptcy probability is the same across entrepreneurs, independent of their net worth. However, the authors point this out as one of the shortcomings of their model.

The only theoretical business cycle model we are aware of that explicitly focuses on the share of entrepreneurs in the labor force is that of Rampini (2004). In this real business cycle model, the risk associated with entrepreneurial activity implies that the amount of such activity should be procyclical, which also results in the amplification and intertemporal propagation of productivity shocks. Agents are assumed to be risk-averse and can choose between a risk-free production technology (wage employment) and a risky production technology (entrepreneurship). Productivity shocks shift the output of both technologies by a constant. As a result, all agents are wealthier during economic booms. The risk-free production technology is always available, which implies no structural unemployment. Furthermore, it is assumed that the expected value of risky entrepreneurship exceeds the opportunity costs of risk-free employment. Hence, all agents prefer entrepreneurship to employment. However, the share of entrepreneurs is restricted by a financial intermediary that determines the optimal rate of entrepreneurship, given the productivity shock of the period and the wealth and preferences of the agents. The intermediary designs an optimal incentive contract that allows entrepreneurs to insure a part of their risk by leverage. Because all agents are wealthier as a result of positive productivity shocks and because risk aversion is assumed to decrease with wealth, it is optimal to have a higher share of entrepreneurs during economic booms. ${ }^{4}$ Furthermore, it is also argued in the spirit of Bernanke and Gertler (1989) that agency costs are countercyclical because more utility is lost due to the moral hazard problem when productivity is low. Hence, Rampini (2004) concludes that entrepreneurship is procyclical, even if agents have access to financial intermediaries.

Aside from these direct analyses of the relationship between entrepreneurship and the business cycle, several labor market-related effects have been identified in the

\footnotetext{
${ }^{4}$ Alternatively, one might argue that risk preferences remain constant over time, but the higher level of wealth of agents during booms reduces liquidity constraints and hence increases entrepreneurial activity (Evans \& Jovanovic, 1989).
}

entrepreneurship literature. A literature survey by Parker (2009) discusses evidence from the United States that new firm formation is procyclical. He also points to the effect of falling wages in recessions, which may lower the opportunity costs for starting a business and encouraging marginal types of entrepreneurship. Yet low-quality businesses may be removed in recessions, exerting a countervailing force on the total number of business owners. Congregado et al. (2009) discuss the recession-push and prosperity-pull concepts, as well as numerous studies supporting these concepts. The recession-push argument would lead to a countercyclical and the prosperity-pull argument to a procyclical effect. $^{5}$

The vast majority of the business cycle literature, however, does not explicitly model entrepreneurial activity. This implies the hypothesis that entrepreneurship is either independent of the cycle or irrelevant for the real economy. The results are mixed and often indirect in the entrepreneurship literature (Thurik et al., 2008; Congregado et al., 2009). This ambiguity does not lead to dominant hypotheses. Hence, we will focus on the data and link our results to the existing literature afterward.

\section{Analysis}

In general, there are two ways of analyzing our data: observations can be averaged across countries to focus on global trends or coefficients can be averaged, putting more emphasis on national conditions. Of course, the two approaches address somewhat different questions: the first investigates if global trends in entrepreneurial activity exist and how they relate to the cycles of the world economy; the second approach investigates the average relationship between entrepreneurship and the cycle at the national level. These two perspectives are likely to yield diverging results if different factors influence the data at the aggregate and national levels. For example, low-skilled individuals who consider starting a business are more likely to be influenced by national labor market policies than by global technological trends, whereas the opposite can be expected for highly skilled opportunity entrepreneurs. Because the former constitute the majority of entrepreneurs (Kirchhoff, 1994), one can expect to find different relationships between unemployment and entrepreneurial activity at the national and global levels if labor market conditions are imperfectly correlated across countries.

Furthermore, economic variables at the country level are more likely to be influenced by national policies and the conditions in specific, closely related nations. The world economy is hardly influenced by the idiosyncratic policies of particular countries. Instead, global-scale business cycle fluctuations more directly reflect developments of global importance, such as major geopolitical changes, world mar-

\footnotetext{
${ }^{5}$ See also Thurik et al. (2008) and Parker (2009) discussing the interplay between unemployment and entrepreneurship.
} 
ket prices of commodities, or technological breakthroughs. Of course, these global developments also have an impact on national business cycles, but the additional influence of national policies and conditions leads to country-specific patterns and dilutes the correlation of cycles across countries.

This section has three parts. First, we present the global results of the comovement of GDP, unemployment, and business ownership using data from 22 OECD countries for the period 1972 to 2007 . The second part deals with the comovement of these variables at the country level. The third part is a robustness check we carried out using a different data source, with the aim of replicating the results of our initial analysis using an alternative measure of entrepreneurship.

\section{A. Aggregate Analysis of Entrepreneurship, Unemployment, and the Cycle}

We construct a balanced cross-country panel of 22 OECD countries with annual data for the period 1972 to 2007 using various sources. OECD data are used to determine annual real GDP in constant 2000 prices in national currencies and standardized unemployment rates. ${ }^{6}$

Entrepreneurial activity per country and per year is measured as the share of business owners in the total labor force, ${ }^{7}$ using data from Compendia 2007.1 that corrects for measurement differences across countries and over time. ${ }^{8}$ This is a broad measure of entrepreneurial activity that includes incorporated, self-employed individuals (ownermanagers of incorporated businesses) and (unincorporated) self-employed persons with and without employees; conversely, the measure excludes unpaid family workers. ${ }^{9}$ The business ownership rate also excludes so-called "sideowners," who generate less than $50 \%$ of their income by running their own businesses.

A disadvantage of using business ownership as a measure of entrepreneurial activity is that it does not fully capture early-stage ventures that do not yet generate a substantial contribution to the owner's income. In addition, business ownership rates reflect to some extent the existing industry structures in place rather than the introduction of new economic activity in the Schumpeterian (1934) and Kirznerian

\footnotetext{
${ }^{6}$ The included countries are Australia, Austria, Belgium, Canada, Denmark, Finland, France, Greece, Iceland, Ireland, Japan, Luxembourg, the Netherlands, New Zealand, Norway, Portugal, Spain, Sweden, Switzerland, the United Kingdom and the United States. These are the 23 old OECD countries. We excluded Germany because we are unable to correct for the influence of its unification on the time series.

${ }^{7}$ The total labor force is the sum of the employed and the unemployed.

${ }^{8}$ Data are constructed by EIM (Zoetermeer, NL) on the basis of OECD material. See http://www.ondernemerschap.nl for the data and van Stel (2005) for an explanation of the method. Quarterly data regarding business ownership rates are not available for most countries.

${ }^{9}$ Unpaid family owners can be regarded as irrelevant in measuring the extent of entrepreneurship because they do not own the businesses they work for and do not bear responsibility or risk in the way that "real" entrepreneurs do.
}

Table 1.-Average Correlation of Business Cycle Time Series BeTWEen Countries

\begin{tabular}{cccc}
\hline \hline & GDP & Unemployment & Entrepreneurship \\
\hline Average correlation & 0.34 & 0.39 & 0.06 \\
\hline Based on time series for 22 OECD countries & $1972-2007$, HP-filtered data $(\lambda=6.25)$.
\end{tabular}

(1973) sense. ${ }^{10}$ To address these conceptual shortcomings of business ownership rates as a measure of entrepreneurial activity, we also use data from the Global Entrepreneurship Monitor (GEM) (Reynolds et al., 2005) as a second measure for robustness checks.

Following the convention of defining the business cycle as a series of deviations from long-term trends in GDP data, we decompose time series into trends and cycles using the Hodrick-Prescott filter (Hodrick \& Prescott, 1997), referred to below as the HP filter. The HP filter is a standard method of removing trend movements that has been applied to both actual data and artificial data in numerous studies. ${ }^{11}$ The smoothing parameter $\lambda$ of the filter, which penalizes acceleration in the trend relative to the business cycle component, needs to be specified. Most of the business cycle literature uses quarterly data and a $\lambda$ value of 1,600 , as Hodrick and Prescott (1997) suggested. Unfortunately, business ownership rates are available only on an annual basis in most countries. Because the time period over which aggregation takes place affects the variance in the process at discrete time intervals, the $\lambda$ value must be adjusted. Ravn and Uhlig (2002) show that the appropriate $\lambda$ value for annual data is 6.25 ; this is the value we use for our analysis.

To test if our results are robust to different methods of detrending the data, we repeat all analyses using a $\lambda$ value of 100 and first differences of growth rates. ${ }^{12}$ The main results we present have been computed using the HP filer with a $\lambda$ value of 6.25 . They are not sensitive to the method of detrending. The additional results are reported in the appendix in Koellinger and Thurik (2009).

A first look at the data shows considerable variation of all three series and countries around a stable mean value of zero. Table 1 shows that the series are only weakly corre-

\footnotetext{
${ }^{10}$ Despite these disadvantages, the business ownership rate is widely used: in Thurik et al. (2008), investigating the interrelationships between entrepreneurship and unemployment; in Erken, Dunselaar, and Thurik (2009), measuring the influence of entrepreneurship on total factor productivity; and in Carree et al. (2002), studying the influence of economic development. See also Parker (2009).

${ }^{11}$ See Ravn and Uhlig (2002) and Jaimovich and Siu (2009), for example.

${ }_{12}$ According to additional tests we conducted, the method of detrending influences the spectrum of the resulting series as well as the AR and MA order of variables. The HP filter with a $\lambda=100$ or higher forces a common spectral shape on the series, which is not so much the case for an HP filter with $\lambda=6.25$ and not at all for the first differences of growth rates. Our additional analyses also showed that GDP and unemployment have very similar spectra, while business ownership exhibits different peaks in the spectrum. ARMA specification tests using the Hannan-Rissanen (1982) procedure showed that GDP and unemployment have more complex AR and MA orders than business ownership.
} 
Figure 1.-Average Deviations of real GDP and Business Ownership Rates from Trend in Percent across 22 OeCD Countries, HP-Filtered Data ( $\lambda=6.25$ )

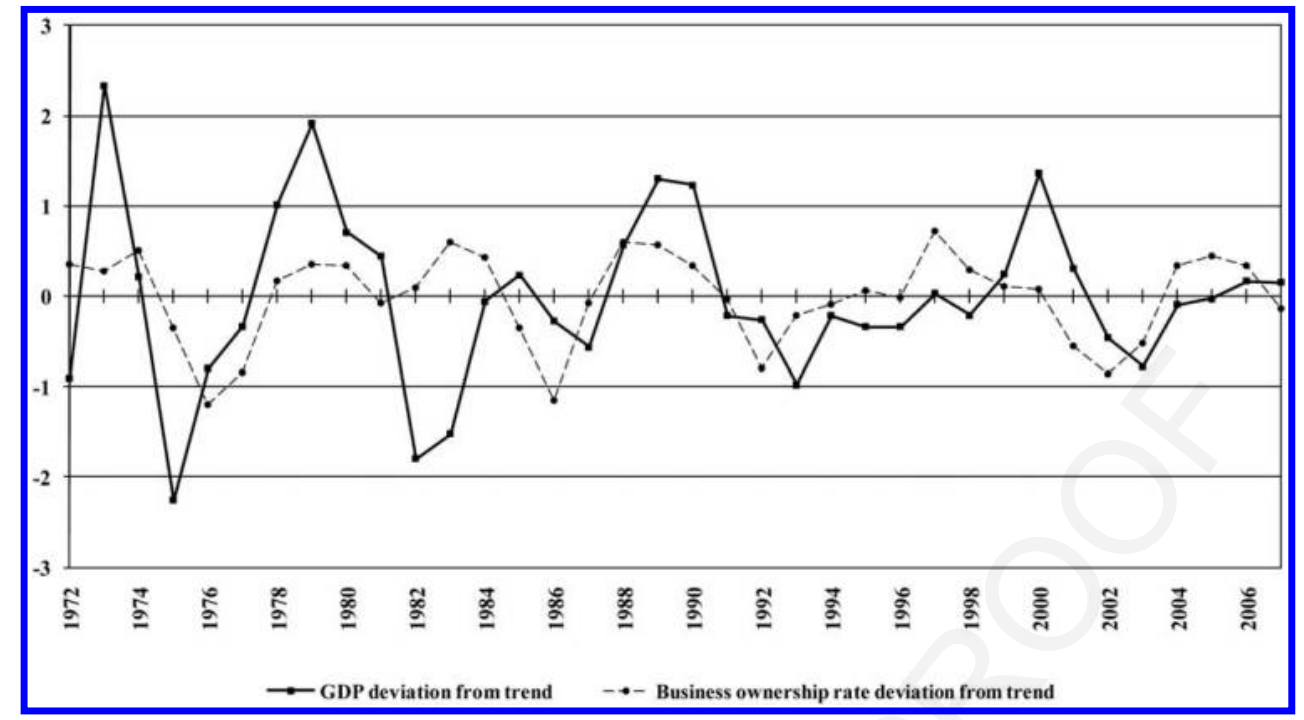

lated across countries. While the GDP series of some countries are strongly correlated (e.g., the Netherlands and Belgium, the United States, and Canada), the series of other countries are independent (e.g., Spain and New Zealand) or even negatively correlated (e.g., Austria and Australia). The same holds for the unemployment series. The average of the correlation coefficients across countries is 0.34 for GDP and 0.39 for unemployment. The pattern in the data indicates a strong correlation of business cycles in countries that are geographically close or economically integrated, such as the European Union. The weakest systematic correlation across countries is shown by the entrepreneurship series, with an average correlation of only 0.06 . This suggests that entrepreneurial activity at the country level exhibits considerable noise that disguises global trends.

To reveal these global trends, we aggregate observations across countries after detrending the original data. Observations of every country are weighted by the economic size of each country, using the average share of each country's GDP in the total GDP of all countries included in the analysis from 1972 to 2007. We use GDP in current prices and current USD to compute these weights. This yields time series for the world economy that smooth out most of the national idiosyncrasies. We also experiment with unweighted data and different weighting methods and find that our main results reported below are not sensitive to weighting. ${ }^{13}$

Figure 1 shows average deviations of world GDP (corrected for inflation) and entrepreneurship from their longterm trends from 1972 to 2007. At least four major cycles are clearly visible: (a) the deep double-dip of the oil crisis in the early 1970s, (b) the recovery and boom of 1979, (c) the boom of 1989, and (d) the high-tech boom of 2000, with the subsequent recession in 2001. Following the 2001 recession is a gradual recovery until 2007. Casual observation of

\footnotetext{
${ }^{13}$ Results are available from the authors on request.
}

the two graphs suggests at least two phenomena. First, economic recoveries and boom periods since the 1980s typically have been preceded by rising levels of entrepreneurship. In particular, the 1989 boom, the high-tech boom of 2000, and the recovery from the recession after 2001 are led by a rise in entrepreneurial activity. Second, cyclical entrepreneurship typically reaches its maximum and starts declining just before a cyclical boom in GDP reaches its maximum. The only exceptions to this trend are the oil crisis and the boom of 1979. Both observations suggest that entrepreneurship is a leading indicator of the business cycle in the time frame we consider.

As expected, a descriptive analysis of GDP and unemployment shows that unemployment is strongly countercyclical. The contemporaneous correlation between the two series is -0.9 (significant at more then $99 \%$ confidence). A countercyclical relationship between GDP and entrepreneurship can be clearly rejected since the contemporaneous correlation between the two series is positive (0.3, significant at over $90 \%$ confidence). A feedback between unemployment and entrepreneurship seems likely because labor market opportunities determine to a large extent the opportunity costs of entrepreneurship (Thurik et al., 2008). Indeed, the contemporaneous correlation between unemployment and entrepreneurship is -0.43 (significant at more then $98 \%$ confidence).

This interrelation between GDP, unemployment, and entrepreneurship suggests a joint analysis of these three variables in an autoregressive context. Given the stationarity of detrended data, we estimate a vector autoregression model with two lags, VAR(2), including deviations from trends in terms of business ownership, real GDP, and unemployment (Lütkepohl, 2007; Greene, 2003). ${ }^{14}$ The optimal lag length

\footnotetext{
${ }^{14}$ There is no indication of unit roots in any of the series included in the model according to the augmented Dickey-Fuller (1979) test at 99\% confidence levels, using Davidson and MacKinnon (1993) critical values.
} 


\begin{tabular}{|c|c|c|c|c|c|c|}
\hline & \multicolumn{2}{|c|}{$Y_{1}=G D P$} & \multicolumn{2}{|c|}{$Y_{2}=$ Unemployment } & \multicolumn{2}{|c|}{$Y_{3}=$ Entrepreneurship } \\
\hline & Coefficient & s.e. & Coefficiend & s.e. & Coefficient & s.e. \\
\hline$G D P(t-1)$ & $0.89 * * *$ & $(0.31)$ & $-6.12 * * *$ & (1.69) & 0.10 & $(0.17)$ \\
\hline$G D P(t-2)$ & -0.56 & $(0.36)$ & $4.62 * *$ & (1.98) & 0.01 & $(0.20)$ \\
\hline Unempl $(t-1)$ & 0.07 & $(0.06)$ & -0.19 & $(0.31)$ & 0.01 & $(0.03)$ \\
\hline Unempl $(t-2)$ & $-0.06^{*}$ & $(0.05)$ & 0.30 & $(0.26)$ & 0.01 & $(0.03)$ \\
\hline $\operatorname{Ent}(t-1)$ & $0.65 * *$ & $(0.27)$ & $-3.95 * *$ & $(1.50)$ & $0.71 * * *$ & $(0.15)$ \\
\hline Ent $(t-2)$ & $-0.67 * *$ & $(0.28)$ & $2.96^{*}$ & $(1.56)$ & $-0.54 * * *$ & $(0.16)$ \\
\hline \multicolumn{7}{|c|}{ Model Diagnostics } \\
\hline \multicolumn{5}{|c|}{ Portmanteau (16) test of residual autocorrelation, modified (Ahn, 1988) } & 0.04 & \\
\hline \multicolumn{5}{|c|}{ LJB test for nonnormality of residuals (Doornik \& Hansen, 2008) } & 0.98 & \\
\hline \multicolumn{5}{|c|}{ LMF (5) statistic of residual autocorrelation (Edgerton \& Shukur, 1999) } & 0.12 & \\
\hline \multicolumn{5}{|c|}{ MARCHLM (2) (Lütkepohl \& Krätzig 2004) } & 0.57 & \\
\hline
\end{tabular}

Significance at $*>90 \%$ confidence; $* *>95 \%$ confidence; $* * *>99 \%$ confidence. HP-filtered data $(\lambda=6.25)$

Table 3.-Granger-Causality Wald Tests on World Economy

\begin{tabular}{|c|c|c|c|}
\hline \multirow[b]{2}{*}{ Regressor } & \multicolumn{3}{|c|}{ Dependent Variable in Regression } \\
\hline & $G D P$ & Unemployment & Entrepreneurship \\
\hline$G D P$ & & 0.00 & 0.85 \\
\hline Unempoyment & 0.15 & & 0.89 \\
\hline Enrepreneurship & 0.02 & 0.02 & \\
\hline
\end{tabular}

of 2 is unanimously suggested by the Akaike (1974) information criterion, the Hannan-Quinn (1979) criterion, and the Schwarz (1978) criterion for $1<p_{\max }<7$.

Our reduced-form VAR(2) expresses each variable as a linear function of its own two past values and the two past values of the other two variables. The vector of errors is assumed to be serially uncorrelated with contemporaneous covariance across equations. Specifically, we estimate

$$
\bar{y}_{t}=\bar{v}+\overline{A_{1}} \overline{y_{t-1}}+\overline{A_{2}} \overline{y_{t-2}}+\overline{u_{t}}
$$

where $\overline{y_{t}}=\left(y_{1 t}, y_{2 t}, y_{3 t}\right)^{\prime}$ is a $3 \times 1$ random vector with, $y_{1}=$ real GDP cycle, $y_{2}=$ unemployment cycle, and $y_{3}=$ business ownership cycle. $\overline{A_{1}}$ and $\overline{A_{2}}$ are fixed $3 \times 3$ matrices of parameters, $\bar{v}$ is a $3 \times 1$ vector of fixed parameters, and $\overline{u_{t}}$ is assumed to be white noise; that is,

$$
\begin{aligned}
& E\left(\overline{u_{t}}\right)=0 \\
& E\left(\overline{u_{t} u_{t}^{\prime}}\right)=\Sigma \\
& E\left(\overline{u_{t} u_{s}^{\prime}}\right)=0 \forall t \neq s .
\end{aligned}
$$

The model is estimated with least squares. Confidence intervals are based on common $t$-values, which have been shown to yield reasonably accurate estimates even for small samples (Lütkepohl, 2007).

Table 2 shows the parameter estimates. The coefficients suggest that entrepreneurship forecasts GDP upswings and unemployment downswings one year in advance. A twoyear lag of entrepreneurship seems to predict the next business cycle turnaround.
The model test statistics show that nonnormality of the residuals is of no concern. There is some indication of remaining autocorrelation in the error terms. However, plots show that none of the autocorrelations reach significance at any lag length, but some partial autocorrelations at longer lags ( $L^{3}$ and higher) are significant. ${ }^{15}$ Varying the lag length of the VAR model does not change this (instead, the residual autocorrelation seems to become stronger). In addition, the multivariate $\mathrm{ARCH}$ test does not raise any concerns about heteroskedasticity either. Alternative methods of detrending the data do not result in models with remaining autocorrelation, although they show similar relationships between entrepreneurship, GDP, and unemployment (see the appendix in Koellinger \& Thurik, 2009). Hence, we conclude that the model in table 2 captures the dynamics in the data reasonably well.

Table 3 reports the result of the corresponding Granger causality tests (Granger, 1969). Fluctuations in entrepreneurship help to predict GDP with $98 \%$ confidence. Hence, we conclude that fluctuations in global trends of entrepreneurship Granger-cause the world business cycle. Furthermore, they predict future unemployment with $98 \%$ confidence. However, the reverse is not true. Neither GDP nor unemployment can forecast future entrepreneurship at the aggregate level.

Based on the estimates from equation (1), we compute orthogonalized impulse response functions (Sims, 1980) that allow us to investigate the thought experiment of how a random shock in entrepreneurship affects real GDP and unemployment in a later phase, holding everything else constant.

Figure 2 shows that an unexpected $1 \%$ rise in entrepreneurship is followed by a $0.19 \%$ rise in real GDP in year $t+1$. This is a considerably strong positive impulse on the world economy. The plotted $90 \%$ bootstrap confidence interval suggests that the effect is highly significant in the first year after the impulse. In subsequent years, the positive effect of the entrepreneurship shock levels out. Hence, we conclude that global entrepreneurship trends are a leading

\footnotetext{
15 The plots are available from the authors on request.
} 
Figure 2.-EFfect of a Shock in Business Ownership (1\%) to REAl GDP, HP-Filtered Data $(\lambda=6.25)$

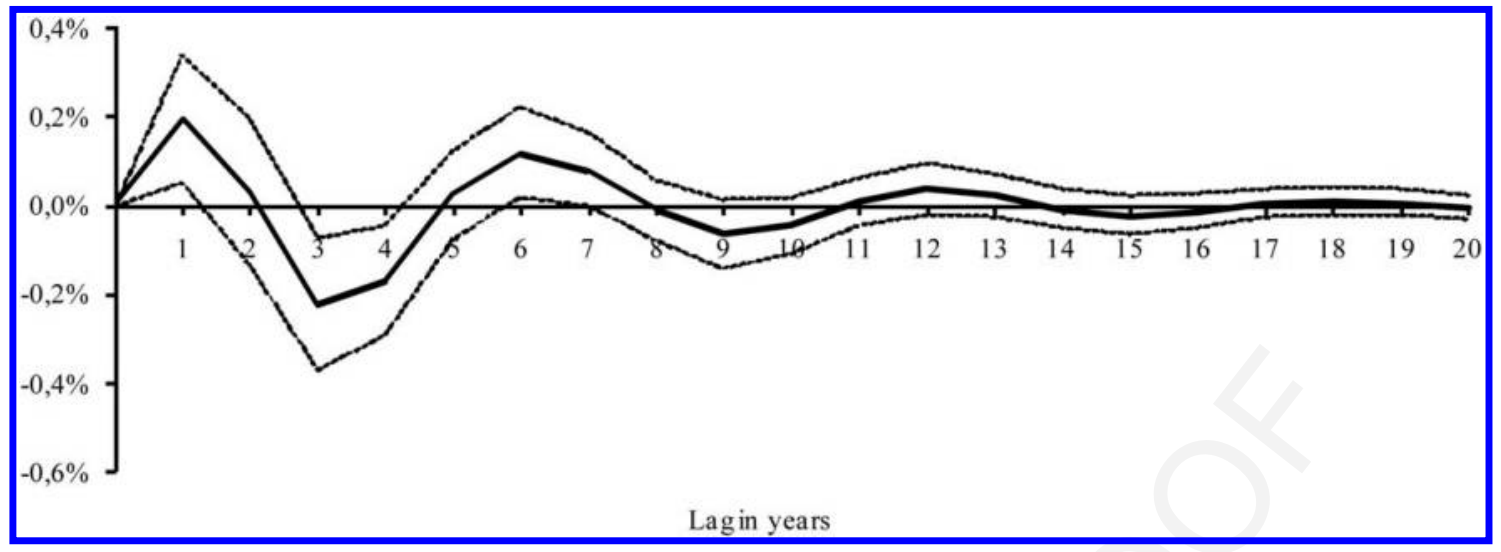

Orthogonalized impulse response function in the business-ownership/unemployment/real-GDP VAR(2), with $90 \%$ bootstrapped confidence interval.

Figure 3.-EfFect of a Shock in Business Ownership (1\%) to Unemployment, HP-Filtered Data $(\lambda=6.25)$

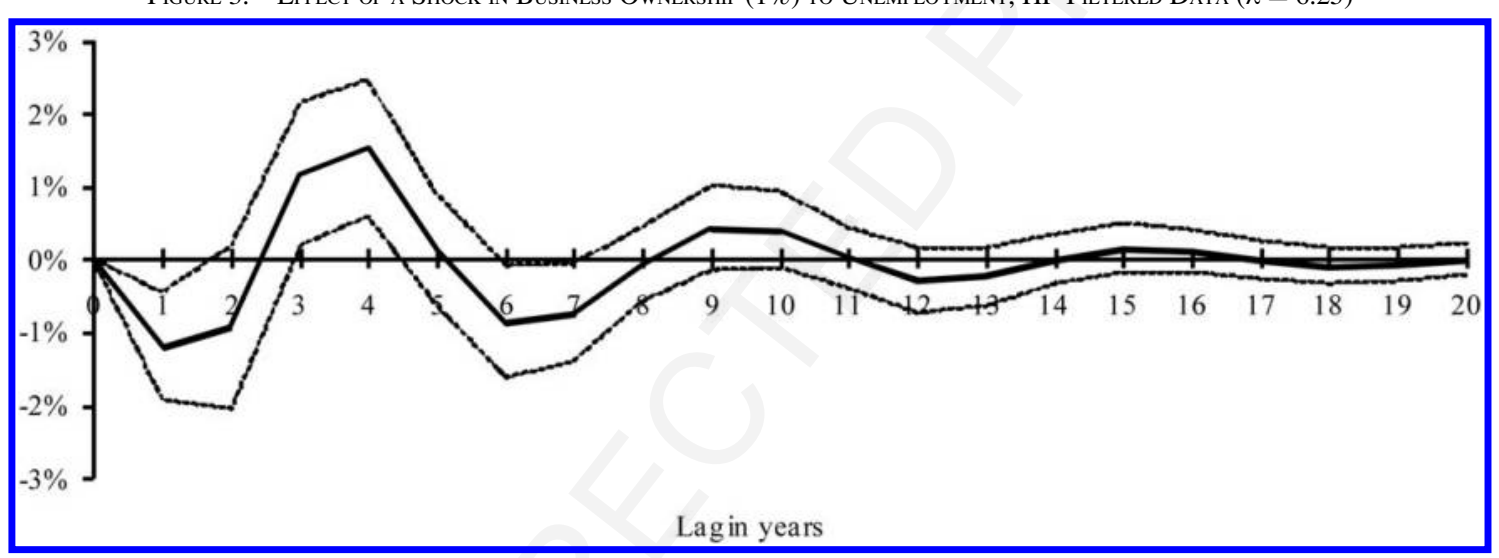

Orthogonalized impulse response function in the business-ownership/unemployment/real-GDP VAR(2), with $90 \%$ bootstrapped confidence interval.

indicator of the world business cycle and Granger-cause upswings.

Similarly, the impulse response function in figure 3 shows that an unexpected increase in the global entrepreneurship leads to a decrease in unemployment one year later. The effect is also significant at over $90 \%$ confidence. Again, the effect of the entrepreneurship shock levels off in later years as the cycle progresses. Although this pattern is partly a result of the general upswing in economic activity that tends to follow an expansion of entrepreneurial activity, it is equally possible that part of the effect stems from the additional economic activity and the jobs created by new firms. ${ }^{16}$

In summary, these observations suggest that an impulse from global entrepreneurial activity is typically followed by

\footnotetext{
${ }^{16}$ For example, in a study covering the establishment of all private sector firms in Denmark, Malchow-Møller, Schjerning, and Sørenson (2009) estimate that $8 \%$ of total gross job creation in the economy is traceable to entrepreneurial firms.
}

a recovery of the world economy and a decrease in unemployment.

\section{B. Country-Level Analysis of Entrepreneurship, Unemployment, and the Cycle}

We replicate the VAR model of section IIA for every individual country. Consistent with Golpe (2009) and Congregado et al. (2009), we find considerable heterogeneity of coefficients across countries. Table 4 shows that only 7 out of 22 countries exhibit significant Granger causality of entrepreneurship on the cycle $(p<0.10)$. It is also noteworthy that the aggregate result (Granger causality Wald test of 0.02; see table 3 ) is in excess of the value in 21 out of 22 individual countries. We conclude that the aggregate result across countries is not driven by a few countries that exhibit a particularly strong relationship between entrepreneurship and the cycle.

An obvious way to aggregate coefficients across countries is to use panel estimators. It is noteworthy that detrending the data removes country fixed effects. This is 
Table 4.-Granger Causality of Business Ownership on Real GDP Cycles ACROSS COUNTRIES

\begin{tabular}{lclc}
\hline \hline Country & $\begin{array}{c}\text { Granger } \\
\text { Causality } \\
\text { Wald test }\end{array}$ & \multicolumn{1}{c}{ Country } & $\begin{array}{c}\text { Granger } \\
\text { Causality } \\
\text { Wald test }\end{array}$ \\
\hline Australia & 0.09 & Japan & 0.10 \\
Austria & 0.07 & Luxembourg & 0.15 \\
Belgium & 0.07 & Netherlands & 0.45 \\
Canada & 0.27 & New Zealand & 0.29 \\
Denmark & 0.28 & Norway & 0.07 \\
Finland & 0.90 & Portugal & 0.48 \\
France & 0.37 & Spain & 0.07 \\
Greece & 0.38 & Sweden & 0.87 \\
Iceland & 0.62 & Switzerland & 0.36 \\
Ireland & 0.07 & United Kingdom & 0.71 \\
Italy & 0.58 & United States & 0.01 \\
\hline Results were computed from, country-specific VARs for the period 1972-2007 using HP-filtered data \\
$(\lambda=6.25)$.
\end{tabular}

reflected in almost identical results for OLS, fixed effects, and Blundell and Bond (1998) system GMM estimations. Unfortunately, there are still several caveats connected to applying these standard techniques in our application. ${ }^{17} \mathrm{We}$ choose to report fixed-effects estimations because they provide a conservative lower bound for the true coefficients. ${ }^{18}$

The coefficient of entrepreneurship in $t-1$ still has the same sign as in the aggregate VAR model, but it is no longer significant. Hence, while entrepreneurship Grangercauses the world business cycle, this is not necessarily the case at the national level. Past values of GDP, unemployment, and entrepreneurship at the country level (table 5) appear to be less informative about future economic development than at the level of the world economy (table 2), possibly due to random policy shocks at the country level that add unexplained variance to the data.

Furthermore, in contrast to the aggregate results in table 2, in which business ownership rates could not be predicted by past values of GDP and unemployment, the picture is different at the level of individual countries. As table 4 shows, unemployment does have a positive effect on future business ownership rates. Intuitively, national labor market conditions influence the opportunity costs of people who

\footnotetext{
${ }^{17}$ The caveats: First, regressions have to be carried out for every dependent variable of the system separately, ignoring the covariance of error terms among the three equations. Second, panel estimators are developed for situations with "small $T$ and large $N$." Because our panel has a very small $N$ of 22 and a medium-sized $T$ of 34, the asymptotic results of these estimators do not necessarily carry over to our application. Third, although at least system GMM allows for heteroskedasticity and autocorrelation within countries but not across them, the close economic relationships among many countries in our sample and the ignored interdependence of the three estimated equations make it plausible that some heteroskedasticity and autocorrelation remain in the models. Fourth, Pesaran and Smith (1995) point out that the average effect cannot be consistently estimated in dynamic panels when coefficients vary across countries because incorrectly ignoring coefficient heterogeneity causes serial correlation in the error term. The aggregation we perform in section IIA circumvents these problems.

${ }^{18}$ If fixed effects were present in the data, the dynamic panel bias would make simple OLS upward biased and fixed-effects regression downward biased, providing upper and lower bounds for the true coefficients (Bond, 2002).
}

consider starting a business (Lucas, 1978; Iyigun \& Owen, 1998). While falling unemployment and better labor market opportunities depress new start-up activities, the opposite is true when unemployment rises. In this case, entrepreneurship is often an escape route for people who have lost their jobs to make a living. This effect has been labeled the "supply push" in the literature. ${ }^{19}$ Hence, while entrepreneurship seems to fluctuate independent of the business cycle at the aggregate level, it does respond to cyclical labor market conditions at the national level.

\section{Robustness Check Using GEM Data}

As a robustness check, we examine a second measure of entrepreneurial activity from a different data source, the Global Entrepreneurship Monitor (GEM) survey for the period 2001 to 2006. Essential in the GEM data collection is the recognition that setting up a business is a process involving various engagement levels (Grilo \& Thurik, 2008; van der Zwan, Thurik, \& Grilo, 2010). The GEM data also allow for the investigation of different motives and degrees of innovativeness among entrepreneurs.

GEM is currently the largest and most widely recognized cross-country research initiative used to study the prevalence, determinants, and consequences of entrepreneurial activity. The core activity of GEM is the annual compilation of data on entrepreneurial activity based on a random sample of at least 2,000 adult-age individuals in each of the participating countries (Reynolds et al., 2005). The GEM survey uses three questions to identify nascent entrepreneurs:

"Over the past twelve months, have you done anything to help start a new business, such as looking for equipment or a location, organizing a start-up team, working on a business plan, beginning to save money, or any other activity that would help launch a business?" (yes, no, don't know/refuse)

"Will you personally own all, part, or none of this business?" (all, part, none, don't know/refuse)

"Has the new business paid any salaries, wages, or payments in kind, including your own, for more than three months?" (yes, no, don't know/refuse)

An individual is coded as a nascent entrepreneur if he or she answers "yes" to question 1, "all" or "part" to question 2 , and "no" to question 3. Thus, a nascent entrepreneur is defined as someone who, during the twelve months preceding the survey, has done something tangible to start a new

\footnotetext{
${ }^{19}$ Oxenfeldt (1943) argued that unemployed individuals or individuals with low prospects for wage employment may become self-employed to earn a living. This effect of unemployment, lowering the opportunity costs of self-employment and driving individuals to start their own businesses, is often referred to as the "supply push" or the "push effect of unemployment." Evidence of this effect has been provided in many studies (Storey \& Jones, 1987; Foti \& Vivarelli, 1994; Audretsch \& Vivarelli, 1996; Thurik et al., 2008; Schaffner, 1993).
} 


\begin{tabular}{|c|c|c|c|c|c|c|}
\hline & \multicolumn{2}{|c|}{$Y_{1}=G D P$} & \multicolumn{2}{|c|}{$Y_{2}=$ Unemployment } & \multicolumn{2}{|c|}{$Y_{3}=$ Entrepreneurship } \\
\hline & Coefficient & s.e. & Coefficient & s.e. & Coefficient & s.e. \\
\hline$G D P(t-1)$ & $0.36 * *$ & $(0.04)$ & $-2.03 * *$ & $(0.35)$ & 0.03 & $(0.05)$ \\
\hline$G D P(t-2)$ & $-0.26^{* *}$ & $(0.04)$ & 0.30 & $(0.30)$ & -0.01 & $(0.05)$ \\
\hline Unempl $(t-1)$ & -0.01 & $(0.00)$ & $0.33^{* *}$ & $(0.04)$ & 0.01 & $(0.01)$ \\
\hline Unempl $(t-2)$ & $0.01 * *$ & $(0.00)$ & $-0.25 * *$ & $(0.03)$ & $0.01^{*}$ & $(0.01)$ \\
\hline $\operatorname{Ent}(t-1)$ & 0.04 & $(0.03)$ & -0.17 & $(0.23)$ & $0.07 * *$ & $(0.04)$ \\
\hline $\operatorname{Ent}(t-2)$ & 0.03 & $(0.03)$ & 0.06 & $(0.23)$ & $-0.35 * *$ & $(0.04)$ \\
\hline
\end{tabular}

All models include time dummies and a constant and including time dummies. OLS and one-step system GMM estimators (with 136 instruments, collapsed) deliver almost identical results. $N=22, T=32$, observations $=726$. Significance at $* 90 \%$ confidence, ${ }^{* *}>95 \%$ confidence. HP-filtered data $(\lambda=6.25)$.

Table 6.-Cyclical Time Patterns of Real GDP with Nascent Entrepreneurial Activity

\begin{tabular}{|c|c|c|c|c|c|c|c|}
\hline \multirow[b]{2}{*}{ Lags in Years } & \multicolumn{7}{|c|}{ Bivariate Correlation of Real GDP Cycle (Year $t$ ) with } \\
\hline & $t-3$ & $t-2$ & $t-1$ & $t$ & $t+1$ & $t+2$ & $t+3$ \\
\hline Nascent entrepreneurship & $\begin{array}{c}0.112 \\
(N=72)\end{array}$ & $\begin{array}{l}0.1921 * \\
(N=92)\end{array}$ & $\begin{array}{c}0.09 \\
(N=109)\end{array}$ & $\begin{array}{c}0.00 \\
(N=109)\end{array}$ & $\begin{array}{c}-0.05 \\
(N=109)\end{array}$ & $\begin{array}{c}-0.08 \\
(N=109)\end{array}$ & $\begin{array}{c}-0.12 \\
(N=109)\end{array}$ \\
\hline Innovative nascent entrepreneurship & $\begin{array}{c}0.0608 \\
(N=55)\end{array}$ & $\begin{array}{l}0.229 * * \\
(N=55)\end{array}$ & $\begin{array}{c}0.2218 \\
(N=55)\end{array}$ & $\begin{array}{c}-0.00 \\
(N=55)\end{array}$ & $\begin{array}{c}-0.13 \\
(N=55)\end{array}$ & $\begin{array}{c}-0.22 \\
(N=55)\end{array}$ & $\begin{array}{c}-0.07 \\
(N=55)\end{array}$ \\
\hline Imitative nascent entrepreeneurship & $\begin{array}{c}0.02 \\
(N=55)\end{array}$ & $\begin{array}{c}0.20 \\
(N=55)\end{array}$ & $\begin{array}{c}0.15 \\
(N=55)\end{array}$ & $\begin{array}{c}0.12 \\
(N=55)\end{array}$ & $\begin{array}{c}-0.05 \\
(N=55\end{array}$ & $\begin{array}{c}-0.17 \\
(N=55)\end{array}$ & $\begin{array}{c}-0.02 \\
(N=55)\end{array}$ \\
\hline Opportunity nascent entrepreneurship & $\begin{array}{c}0.13 \\
(N=71)\end{array}$ & $\begin{array}{c}0.21^{*} \\
(N=91)\end{array}$ & $\begin{array}{c}0.07 \\
(N=108)\end{array}$ & $\begin{array}{c}0.00 \\
(N=108)\end{array}$ & $\begin{array}{c}-0.07 \\
(N=108)\end{array}$ & $\begin{array}{c}-0.08 \\
(N=108)\end{array}$ & $\begin{array}{c}-0.11 \\
(N=108)\end{array}$ \\
\hline Necessity nascent entrepreneurship & $\begin{array}{c}-0.06 \\
(N=71)\end{array}$ & $\begin{array}{c}0.11 \\
(N=91)\end{array}$ & $\begin{array}{c}0.18 * * \\
(N=108)\end{array}$ & $\begin{array}{c}0.14 \\
(N=108)\end{array}$ & $\begin{array}{c}0.06 \\
(N=108)\end{array}$ & $\begin{array}{c}-0.01 \\
(N=108)\end{array}$ & $\begin{array}{c}-0.11 \\
(N=108)\end{array}$ \\
\hline
\end{tabular}

Zealand, Norway, Portugal, Spain, Sweden, Switzerland, United Kindom, and United States.

firm, expects to own at least part of this new firm, and has not paid wages for more than three months. ${ }^{20} \mathrm{GEM}$ data on the prevalence of nascent entrepreneurs as a percentage of the adult population are available for all of the 22 OECD countries in our previous exercise for the time period 2001 to 2006, with the exception of Luxembourg. However, not all countries participated in GEM every year, and this yields an unbalanced panel structure.

An advantage of using GEM data is that nascent entrepreneurs are categorized by their start-up motives (opportunity versus necessity) and by the self-evaluated innovativeness of their ventures. Hence, we can examine whether different types of entrepreneurship show different patterns of relation to the business cycle. The differentiation between opportunity and necessity entrepreneurs is available for the entire time period 2001 to 2006 . Each nascent entrepreneur is asked if he or she is involved in the start-up or firm to take advantage of a business opportunity or because he or she has no better choices for work (Reynolds et al., 2005). Below, we consider the share of opportunityand necessity-bound nascent entrepreneurs, leaving aside those who said they engaged for both reasons or did not know.

In addition, the GEM surveys for 2002 to 2004 included three follow-up questions related to the innovativeness of the business ideas of individuals who qualify as nascent entrepreneurs. These follow-up questions ask each nascent

\footnotetext{
${ }^{20}$ GEM uses the information on the duration that wages have been paid to differentiate nascent, young, and established entrepreneurs.
}

entrepreneur about the novelty of the technology he or she attempts to use, the novelty of the product or service to potential customers, and the expected degree of competition in the market he or she wishes to enter (Hessels, ven Gelderen, \& Thurik, 2008). Hence, these questions can be used to construct a profile of the innovativeness of business ideas pursued by nascent entrepreneurs. We define purely imitative entrepreneurs as nascent entrepreneurs who have neither a product nor a process innovation and expect many business competitors in the market they enter (Koellinger, 2008; Koellinger \& Minniti, 2009).

Because of the short time frame for which GEM data are available, it does not lend itself to detrending and an autoregressive analysis. ${ }^{21}$ Instead, table 6 summarizes the bivariate correlations of the lagged variables using panel data instead of aggregated data. Similar to the results in table 2, we find that an increase in nascent entrepreneurial activity is followed by a significant increase in GDP two years later. The strongest positive correlation between nascent entrepreneurship and future GDP is found at $t-2$, while the peak in business ownership is a little later, at $t-1$. This is what one should expect given that the GEM measure captures entrepreneurial activity at an earlier stage, before most ventures start to contribute significantly to the entrepreneur's income. Given that the GEM measure is constructed to measure entrepreneurship consistently across countries and is not just a side product of official labor market statistics,

\footnotetext{
${ }^{21}$ The decomposition of GDP in trend and cycle is again computed for the period 1972-2007.
} 
one would also expect that it is a better dynamic measure of entrepreneurial activity in the Schumpeterian (1934) or Kirznerian (1973) sense than is the more static business ownership rate. Hence, finding strong correlations between the GEM measure and future GDP across countries adds credibility to our previous findings.

The comparison between the start-up motives (rows 4 and 5) indicates that opportunity entrepreneurship leads the cycle by two years, while necessity entrepreneurship leads the cycle by only one year. A somewhat speculative explanation for the lag in necessity entrepreneurship has to do with the legitimation or moral approval of entrepreneurship within a culture (Etzioni, 1987). In this case, if there is a higher level of legitimation of entrepreneurship, then it will manifest itself widely, resulting in more attention to entrepreneurship within the educational system, higher social status for entrepreneurs, and more tax incentives to encourage business start-ups. Obviously this results in a higher supply of entrepreneurs. It may be that here, we observe the cyclical variant of what Etzioni proposed as a cross-section structural cause: the opportunity entrepreneurs pave the way for necessity entrepreneurs.

\section{Discussion}

Our results show that global trends in entrepreneurship are an early indicator of the recovery from economic recessions, while entrepreneurship at the national level reacts to unemployment fluctuations instead of causing them. Our discussion focuses on three aspects of these results. First, we discuss the disparity between the results at the aggregate and national levels. Where does it come from? Second, how do our empirical results relate to the theoretical conjectures about entrepreneurship and the cycle? And finally, what are the implications of our finding that entrepreneurship Granger-causes the business cycle, at least at the aggregate level?

\section{A. Differences between the Aggregate and National Cycles}

We see three economic factors that together help to explain the disparity between the aggregate and national levels. $^{22}$

First, not all entrepreneurs are equal in their performance and motivation. This determines their potential impact on the economy. The majority of business start-ups engage in marginal, imitative economic activity (Kirchhoff, 1994; Wennekers \& Thurik, 1999; Koellinger, 2008) or fail shortly after their inception (Dunne, Roberts, \& Samuelson, 1988). ${ }^{23}$ The potential impact of these marginal entrepreneurs on the macroeconomy is likely to be limited. The

\footnotetext{
${ }^{22}$ We believe these economic factors are ultimately more important than the econometric caveats regarding the country level analyses (see note 16$)$.

${ }^{23}$ See Davidsson, Achtenhagen (2010) for a survey of the small firm growth literature.
}

small share of successful, innovative, and high-growth entrepreneurs, however, is likely to make a difference, as the success stories of the Richard Bransons and Steve Jobses of this world demonstrate. These different types of entrepreneurs are likely to be motivated by different factors. Highpotential entrepreneurs react more to the presence of good business opportunities than to a lack of employment alternatives (Bowen \& de Clercq, 2008; Hessels et al., 2008). Good business opportunities are often related to newly invented technologies, geopolitical developments, or changes in commodity prices that are of global importance (Shane, 2003). Hence, nonmarginal entrepreneurship tends to exhibit global peaks whenever business opportunities of global magnitude arise, such as during the IT boom of the late 1990s. Marginal entrepreneurs, however, are more likely to respond to national labor market conditions because they play marginal roles in existing organizations as well. Hence, the increase in unemployment during recessions (Kydland \& Prescott, 1990; Hall, 2005; Elsby, Michaels, \& Solon, 2009) triggers increases in marginal entrepreneurship (Evans \& Leighton, 1990; Caliendo \& Uhlendorff, 2008; Thurik et al., 2008; Faria et al., 2009, 2010). In addition, start-up costs for paying qualified labor (Kydland \& Prescott, 1990) and borrowing capital (King \& Watson, 1996) tend to be lower during recessions. Both factors together contribute to the increase in entrepreneurial activity, in response to recessions, which our results show at the national level.

Second, business cycles across countries are only weakly correlated (see table 1). This is because national business cycles are driven not only by global business conditions but also by unanticipated shocks in government spending, taxes, real estate market bubbles, (de)-regulation, monetary policy, and other nationally relevant factors. One reason for country-specific policy shocks is constituted by political business cycles, which can be triggered by nonrational voters in combination with ideological or opportunistic parties. Because voting cycles are asynchronous across countries, politically motivated shocks to the economy will typically be country specific rather than systematic across countries. $^{24}$ Another reason for country-specific shocks may result from poorly informed policymakers. For example, Leamer (2009) argues that the excessive volatility of U.S. interest rates set by the Fed between 2000 and 2005 contributed to the rise and burst of the U.S. real estate bubble in 2008 and the subsequent recession. Leamer argues further that the Fed was targeting the wrong indicator (inflation) during that period and that a monetary policy focused on preventing the excessive building of homes or cars, with preemptive rate increases in the middle of expansions, would help to smooth out the cycle instead of amplifying it. The combined role of such unanticipated fiscal and mone-

\footnotetext{
${ }^{24}$ Nordhaus, Alesina, and Schultze (1989) provide a comprehensive review of the rich theoretical literature on political business cycles and empirical evidence that speaks strongly against ultrarational voters who would render political cycles ineffective.
} 
tary policy is likely to dominate the effects from mostly marginal entrepreneurial activity at the country level. ${ }^{25}$

National entrepreneurship rates will respond to many country-specific policy shocks, such as national changes in taxation or unemployment benefits. It is reasonable that most entrepreneurs will not be better than consumers at anticipating such policy shocks. Hence, only weakly correlated business cycles across countries in combination with national policy shocks contribute to the almost-zero correlation of entrepreneurial activity across countries, as shown in table 1.

Third, as a consequence of the above, aggregating cyclical fluctuations of GDP, unemployment, and entrepreneurship across countries has a dual effect. First, it filters out national policy shocks on GDP and unemployment, which are likely to dominate the impulse coming from productive entrepreneurial activity. Second, aggregated cyclical data focus on the subset of entrepreneurs who identify technologies and business opportunities that are globally important. Both effects together are more likely to disclose the "real shocks" that the highly productive part of entrepreneurial activity exerts on the economy in aggregated data rather than in national data.

\section{B. Relation to Theoretical Literature}

Our empirical results help to put the previous theoretical literature on the topic into perspective. Clearly, our data reject the null hypothesis that the share of entrepreneurs in the population is independent of the cycle. In addition, our results modify the hypothesis that the share of entrepreneurs is procyclical (Rampini, 2004). Instead of being strictly procyclical, entrepreneurial activity appears to lead the cycle at the global level. This is an important result rather than a nuance because it has repercussions for the conceptual reasons for the interplay of entrepreneurship and the cycle. While accepting Rampini's (2004) logic, we discuss several assumptions that might be responsible for the discrepancy between his theoretical results and our empirical outcomes.

First, Rampini (2004) assumes a decrease in absolute risk aversion of agents. This assumption drives the conclusion that entrepreneurial activity is procyclical because it implies that higher average wealth among agents, as a result of positive productivity shocks, leads to a higher optimal share of entrepreneurs. However, prospective entrepreneurs might not be primarily concerned about expected payoffs in evaluating the attractiveness of different occupational choices. Rather, they might evaluate their current income relative to some reference point, such as average income or their previous income. ${ }^{26}$ Agents who have a current income that falls below

\footnotetext{
${ }^{25}$ A similar effect is known to arise from monetary demand across countries. For example, Arnold (1994) and Arnold and de Vries (2000) point out that the stability of Euro-area monetary demand may be due to desynchronized shocks in monetary demand across countries, which are averaged out through the aggregation process.

${ }^{26}$ The minimum wage level can also be an evaluation point for countries with generous social safety systems. Nooteboom (1985) developed a theory in which retail profit margins are influenced by the minimum wage level. See also Nooteboom and Thurik (1985).
}

this reference point (e.g., as a result of losing their jobs in a recession) may exhibit risk-seeking behavior. ${ }^{27}$ The mechanism leading to procyclical entrepreneurship in Rampini's model would cease to work if a significant share of the population were to exhibit increasing absolute risk aversion or if some agents were risk seeking during recessions.

Second, Rampini (2004) assumes that entrepreneurs on average make profits that exceed their opportunity costs. This seems to be at odds with empirical evidence. New entrepreneurs have extremely high dropout rates. ${ }^{28}$ Such high failure rates have repercussions for the financial attractiveness of entrepreneurship: using U.S. data, Hamilton (2000) shows that staying in a wage job or moving back to it makes more economic sense than does starting a new business, except for the highest $25 \%$ of entrepreneurial incomes. Hence, contrary to expectations, entrepreneurship is a career choice that does not pay on average. In addition, entrepreneurial investments of individuals in their own companies exhibit comparatively low returns. Moskovitz and Vissing-Jørgensen (2002) have investigated the riskreturn profiles of investments in private enterprises and found them to be inferior to investments in publicly traded assets, such as stocks. In essence, empirical evidence suggests that entrepreneurship is not a wise career or investment choice from a purely monetary perspective.

Third, low payoffs to entrepreneurship have been traced to nonfinancial preferences, such as a taste for independence and for being one's own boss (Blanchflower \& Oswald 1998; Blanchflower, 2000; Blanchflower, Oswald, \& Stutzer, 2001; Benz \& Frey, 2008; Block \& Koellinger, 2009), a more varied work experience (Astebro \& Thompson, 2011), and judgmental errors on the part of entrepreneurs, such as overconfidence and excessive optimism (Cooper, Woo, \& Dunkelberg, 1988; Camerer \& Lovallo, 1999; Koellinger, Minniti, Schade, 2007). In the absence of strictly financial preferences and optimal decision making, there is no obvious reason that positive productivity shocks and countercyclical agency costs would imply procyclical entrepreneurship. In fact, one might even argue that the tendency of entrepreneurs to be overconfident leads to an information structure that is opposite the classic principal-agent problem assumed by Bernanke and Gertler (1989), Carlstrom and Fuerst (1997), and Rampini (2004): instead of borrowers being better informed than lenders, it may be that banks are more realistic and more efficient processors of relevant information than are the entrepreneurs seeking financing. ${ }^{29}$

\footnotetext{
${ }^{27}$ See Kahneman and Tversky (1979), Payne, Laughhunn, and Crom (1981), Wehrung (1989), Tversky and Kahneman (1992), and Tversky and Wakker (1995).

${ }^{28}$ For example, Evans and Leighton (1989) report for the United States that about a third of entrants leave self-employment within three years. Similarly, Dunne et al.'s (1988) study of U.S. Census of Manufacturers data purports that on average, $61.5 \%$ of all firms exit in the first five years following the first census in which they are observed.

${ }^{29}$ De Meza and Southey (1996) theoretically demonstrate that this perspective performs better in explaining the stylized facts about entrepreneurship.
} 


\section{Implications}

What are the implications of the finding that entrepreneurship Granger-causes the world business cycle? Obviously the answer to this question depends on whether this empirical pattern is structural.

Entrepreneurial behavior may be a structural cause of economic booms because it can lead to a positive productivity shock during a recession via two mechanisms. First, additional entrepreneurs contribute to aggregate productivity growth by diffusing new technologies and products even if they do not invent them themselves. This can lead to a more efficient use of productive resources in the economy (Schmitz, 1989).

Second, entrepreneurial innovations may lead to aggregate productivity shocks. However, why should it be new firms that innovate more vigorously in response to recessions rather than established firms? One explanation is that innovative ventures are risker and more uncertain than are imitative ventures (Koellinger, 2008). According to prospect theory (Kahneman \& Tversky, 1979), an aversion to high risk and uncertainty is usually observed among individuals who are in a gain position relative to their individual reference points, whereas individuals in a loss position actually seek high risk and uncertainty. Applying this behavioral pattern to business start-up decisions would suggest that innovative business ideas that entail high risk and uncertainty are more likely to be pursued by individuals who suddenly have lower opportunity costs to self-employment than before, for example, as a result of a salary cut or unemployment in a recession (Koellinger, 2008). In other words, the alternative of unemployment can cause people to start businesses premised on rather unusual, innovative ideas. Of course, many of them will ultimately fail, but some will succeed and grow. If the tendency of entrepreneurs to accept higher risks during a recession coincides with the availability of new breakthrough technologies and new business opportunities, more of these new businesses will survive and grow (Audretsch, 1991, 1995), causing a global spike in business ownership rates that forecasts the next economic boom. The reasoning that people are more willing to accept risks during a recession does not carry over to established firms because agents in established firms typically absorb only a small share of the risk of the venture (Hart, 1995) and because large firms are more diversified and therefore exhibit fewer profit fluctuations (Mills \& Schuman, 1985). In fact, there is empirical evidence that innovative activity measured by R\&D spending in established firms is strongly procyclical (Barlevy, 2007).

An alternative reason that new firms instead of established firms innovate during recessions is that established firms face the costs associated with making new production technologies compatible with installed production technologies. New firms do not have to deal with incompatibilities; they start from scratch. Hence, the arrival of new, incompatible technologies will raise investment in new firms and decrease investment in established firms (Jovanovic \& Rousseau, 2009; Yorukoglu, 1998). ${ }^{30}$ Such compatibility costs result in the delayed adoption of new technologies in established firms (Jovanovic \& Stolyarov, 2000). In addition, Klenow (1998) argues that the profits associated with the adoption of a new technology are highest just before a boom. If, for some reason, new firms are quicker to see the new opportunities, then their adoption decisions should lead the boom.

The procyclical R\&D spending of established firms (Barlevy, 2007) is not necessarily at odds with the hypothesis that more entrepreneurial innovation takes place during recessions. The innovative activities of entrepreneurs often remain below the radar of official $R \& D$ measurements because they happen to a large extent before a business is incorporated and becomes part of the official statistics. An instructive example is user innovation-innovation that is developed and applied by end users rather than by suppliers (von Hippel, 1986, 1988). Users have commercialized their innovations and became "user entrepreneurs" in a wide range of industries. ${ }^{31}$ Often user entrepreneurship involves the introduction of radically new technology and, in some cases, the creation of entirely new industries (Baldwin, Hienerth, \& von Hippel, 2006; Tripsas, 2008). Frustrated users are often "accidental" entrepreneurs who stumble across an idea and then share it with others. The innovation happens before the formal evaluation of the idea as the basis of a commercial venture; it is not the result of commercial $R \& D$ activity and remains undetected by $R \& D$ and patent statistics. Shah and Tripsas (2007) argue that user entrepreneurship is more likely if users have relatively low opportunity costs, as would be the case during recessions. Such mechanisms suggest that in addition to more imitative entrepreneurship being a source of aggregate productivity shocks during recessions, it might also be that more innovative entrepreneurship takes place during recessions. If one were willing to accept a causal interpretation of our empirical findings, it would imply that entrepreneurs exert a portion of the real shocks and innovations that drive dynamics in real business cycle models.

Alternatively, entrepreneurial activity may not be the structural cause but simply an early indicator of a coming economic boom. For example, entrepreneurs may be quicker in detecting and reacting to new technologies and business opportunities than established firms, for the reasons we have outlined. Nevertheless, the economic impulse resulting from their nascent business activities might be too small to cause an economic boom. Instead, larger, more established firms are probably slower to realize and adapt to positive productivity shocks, but they might be ultimately responsible for the measurable increase in GDP and the decrease in unem-

\footnotetext{
${ }^{30}$ In the model developed by Jovanovic and Rousseau (2009), the share of entrepreneurs is countercyclical if the source of variation is the cost of capital between old and new firms.

${ }^{31}$ See Shah and Tripsas (2007) for an overview.
} 
ployment. Which of these interpretations is correct is an interesting question for future research.

\section{Conclusion}

Our empirical results of the interplay between the entrepreneurship and the business cycle correspond to the two faces of entrepreneurship. On the one side, entrepreneurs are agents of change and economic development, in a Schumpeterian sense, who anticipate and maybe even trigger economic booms (Baumol, 2002). On the other side, many business owners perform only marginal activities (Kirchhoff, 1994) and escape to entrepreneurship only if no regular jobs are available (Oxenfeldt, 1943). The prevalence of the former effect at the level of the world economy suggests an important and much overlooked function of entrepreneurship in the recovery from recessions.

\section{REFERENCES}

Ahn, Sung K., "Distribution of Residual Autocovariances in Multivariate Autoregressive Models with Structured Parameterization," Biometrika 75 (1988), 590-593.

Akaike, Hirotsugu, "A New Look at the Statistical Model Identification," IEEE Transactions on Automatic Control 19 (1974), 716-723.

Arnold, Ivo J. M., "The Myth of a Stable European Money Demand," Open Economies Review 5 (1994), 249-259.

Arnold, Ivo J. M., and Casper G. de Vries, "Endogeneity and European Money Demand," European Journal of Political Economv 16 (2000), 587-609.

Astebro, Thomas, and Peter Thompson, "Entrepreneurs: Jacks of All Trades or Hobos?" Research Policy 40 (2011), 637-648.

Audretsch, David B., "New Firm Survival and the Technological Regime," this REVIEw 73 (1991), 441-450.

"Innovation, Growth and Survival," International Journal of Industrial Organization 13 (1995), 441-457.

The Entrepreneurial Society (New York: Oxford University Press, 2007).

Audretsch, David B., and A. Roy Thurik, "What Is New about the New Economy: Sources of Growth in the Managed and Entrepreneurial Economies," Industrial and Corporate Change 10 (2001), 267-315.

Audretsch, David B., and Marco Vivarelli, "Firms' Size and R\&D Spillovers: Evidence from Italy," Small Business Economics 8 (1996), 249-258.

Baldwin, Carliss, Christoph Hienerth, and Eric von Hippel, "How User Innovations Become Commercial Products: A Theoretical Investigation and Case study," Research Policy 35 (2006), 1291-1313.

Barlevy, Gadi, "On the Cyclicality of Research and Development," American Economic Review 97 (2007), 1131-1164.

Baumol, William, The Free-Market Innovation Machine (Princeton, NJ: Princeton University Press, 2002).

Benz, Matthias, and Bruno Frey, "Being Independent Is a Great Thing: Subjective Evaluations of Self-employment And hierarchy," Economica 75 (2008), 362-383.

Bernanke, Ben, and Mark Gertler, “Agency Costs, Net Worth, and Business Fluctuations," American Economic Review 79 (1989), 14-31.

Blanchflower, David, "Self-Employment in OECD Countries," Labour Economics 7 (2000), 471-505.

Blanchflower, David, and Andrew Oswald, "What Makes an Entrepreneur?" Journal of Labor Economics 16 (1998), 26-60.

Blanchflower, David, Andrew Oswald, and Alois Stutzer, "Latent Entrepreneurship across Nations," European Economic Review 45 (2001), 680-691.

Block, Joern, and Philipp Koellinger, "I Can't Get No Satisfaction Necessity Entrepreneurship and Procedural Utility," Kyklos 62 (2009), 191-209.

Blundell, Richard, and Stephen Bond, "Initial Conditions and Moment Restrictions in Dynamic Panel Data Models," Journal of Econometrics 87 (1998), 115-143.
Bond, Stephen, "Dynamic Panel Data Models: A Guide to Micro Data methods and Practice," Institute for Fiscal Studies working paper no. $09 / 02$ (2002).

Bowen, Harry P., and Dirk de Clercq, "Institutional Context and the Allocation of Entrepreneurial Effort," Journal of International Business Studies 39 (2008), 747-767.

Caliendo, Marco, and Arne Uhlendorff, "Self-Employment Dynamics, State Dependence and Cross-Mobility Patterns," SOEPpapers on multidisciplinary panel data research, no. 152 (2008). http://www.diw .de/documents/publikationen/73/93247/diw_sp0152.pdf.

Camerer, Colin F., and Dan Lovallo, "Overconfidence and Excess Entry: An Experimental Approach," American Economic Review 89 (1999), 306-318.

Carlstrom, Charles T., and Timothy S. Fuerst, “Agency Costs, Net Worth, and Business Fluctuations: A Computable General Equilibrium Analysis," American Economic Review 87 (1997), 893-910.

Carree, Martin, André van Stel, A. Roy Thurik, and Sander Wennekers, "Economic Development and Business Ownership: An Analysis Using Data of 23 OECD Countries in the Period, 1976-1996," Small Business Economics 19 (2002), 271-290.

Congregado, Emilio, Antonio A. Golpe, and Simon Parker, "The Dynamics of Entrepreneurship: Hysteresis, Business Cycles and Government Policy," IZA discussion paper no 4093 (2009). ftp://repec.iza.org /RePEc/Discussionpaper/dp4093.pdf.

Cooper, Arnold, Carolyn Woo, and William C. Dunkelberg, "Entrepreneurs' Perceived Chances for Success," Journal of Business Venturing 3 (1988), 97-108

Davidsson, Per, Leona Achtenhagen, and Lucia Naldi, "Small Firm Growth," Foundations and Trends in Entrepreneurship 6 (2010), 69-166.

Davidson, Russel, and James G. MacKinnon, Estimation and Inference in Econometrics (New York: Oxford University Press, 1993).

De Meza, David, and Clive Southey, "The Borrower's Curse: Optimism, Finance and Entrepreneurship," Economic Journal 106 (1996), 375-386.

Dickey, David A., and Wayne A. Fuller, "Distribution of the Estimators for Autoregressive Time Series with a Unit Root," Journal of the American Statistical Association 74 (1979), 427-431.

Doornik, Jurgen A., and Henrik Hansen, "An Omnibus Test for Univariate and Multivariate Normality," Oxford Bulletin of Economics and Statistics 70 (2008), 927-939.

Dunne, Timothy, Mark J. Roberts, and Larry Samuelson, "Patterns of Firm Entry and Exit in US Manufacturing Industries," RAND Journal of Economics 19 (1988), 495-515.

Edgerton, David, and Ghazi Shukur, "Testing Autocorrelation in a System Perspective," Econometric Reviews 18 (1999), 343-386.

Elsby, Michael W. L., Ryan Michaels, and Gary Solon, "The Ins and Outs of Cyclical Unemployment," American Economic Journal Macroeconomics 1 (2009), 84-110.

Erken, Hugo, Piet Donselaar, and A. Roy Thurik, "Total Factor Productivity and the Role of entrepreneurship," Tinbergen Institute discussion paper no. 2009-034/3 (2009), http://www.tinbergen.nl /discussionpapers/09034.pdf.

Etzioni, Amitai, "Entrepreneurship, Adaptation and Legitimation," Journal of Economic Behavior and Organization 8 (1987), 175-189.

Evans, David S., and Boyen, Jovanovic, "An Estimated Model of Entrepreneurial Choice Under Liquidity Constraints," Journal of Political Economy 97 (1989), 808-827.

Evans, David S., and Linda S. Leighton, "Some Empirical Aspects of Entrepreneurship," American Economic Review 79 (1989), 519535 .

"Small Business Formation by Unemployed and Employed Workers," Small Business Economics 2 (1990), 319-330.

Faria, João Ricardo, Juan Carlos Cuestas, and Luis A. Gil-Alana, "Unemployment and Entrepreneurship: A Cyclical Relationship? Economics Letters 105 (2009), 318-320.

Faria, João Ricardo, Juan Carlos Cuestas, and Estefanía Mourelle, "Entrepreneurship and Unemployment: A Nonlinear Bidirectional Causality?" Economic Modelling 27 (2010), 1282-1291.

Foti, Alessandro, and Marco Vivarelli, "An Econometric Test of the SelfEmployment Model: The Case of Italy," Small Business Economics 6 (1994), 81-93.

Golpe, Antonio, "Self-Employment and Business Cycles" Ph.D. dissertation, University of Huelva (2009). 
Granger, Clive W. J., "Investigating Causal Relations by Econometric Models and Cross-Spectral Methods," Econometrica 39 (1969), 424-438.

Greene, W., Econometric Analysis, 5th ed. (Upper Saddle River, NJ: Prentice Hall, 2003).

Grilo, Isabel, and Roy Thurik, "Determinants of Entrepreneurial Engagement Levels in Europe and the US," Industrial and Corporate Change 17 (2008), 1113-1145.

Hall, Robert E., "Employment Fluctuations with Equilibrium Wage Stickiness," American Economic Review 95 (2005), 50-65.

Hamilton, Barton H., "Does Entrepreneurship Pay? An Empirical Analysis of the Returns to Self-Employment," Journal of Political Economv 108 (2000), 604-631.

Hannan, Edward J., and Bary G. Quinn, "The Determination of the Order of an Autoregression," Journal of the Royal Statistical Society B 41 (1979), 190-195.

Hannan, Edward J., and Jorma Rissanen, "Recursive Estimation of Mixed Autoregressive-Moving Average Order," Biometrika 69 (1982), 81-94.

Hart, Oliver, "Corporate Governance: Some Theory and Implications," Economic Journal 105 (1995), 678-689.

Hessels, Jolanda, Marco van Gelderen, and Roy Thurik, "Entrepreneurial Aspiration, Motivation and Their Drivers," Small Business Economics 31 (2008), 323-339.

Hodrick. Robert J., and Edward C. Prescott, "Postwar U.S. Business Cycles: An Empirical Investigation," Journal of Monev. Credit and Banking 29 (1997), 1-16.

Hoover, Kevin D., Søren Johansen, and Katarina Juselius, "Allowing the Data to Speak Freely: The Macroeconometrics of the Cointegrated Vector Autoregression," American Economic Review: Papers and Proceedings 98 (2008), 251-255.

Iyigun, Murat F., and Ann L. Owen, "Risk, Entrepreneurship and Human Capital Accumulation," American Economic Review: Papers and Proceedings 88 (1998), 454-457.

Jaimovich, Nir, and Henry E. Siu, "The Young, the Old, and the Restless: Demographics and Business Cycle Volatility," American Economic Review 99 (2009), 804-826.

Jovanovic, Boyan, and Peter L. Rousseau, "Extensive and Intensive Investment over the Business Cycle," NBER working paper no. 14960 (2009). http://www.nber.org/papers/w14960.pdf.

Jovanovic, Boyan, and Dmitriy Stolyarov, "Optimal Adoption of Complementary Technologies," American Economic Review 90 (2000), 15-29.

Juselius, Katarina, "Special Issue on Using Econometrics for Assessing Economic Models-An Introduction," Economics: The OpenAccess, Open-Assessment E-Journal 3 (2009), 1-20.

Kahneman, Danial, and Amos Tversky, "Prospect Theory: An Analysis of Decision under Risk," Econometrica 47 (1979), 263-291.

King, Robert G., and Mark Watson, "Money, Prices, Interest Rates and the Business Cycle," this REvIEw 78 (1996), 35-53.

Kirchhoff, Bruce A., Entrepreneurship and Dynamic Capitalism (Westport, CT: Praeger, 1994).

Kirzner, Israel M., Competition and Entrepreneurship (Chicago: The University of Chicago Press, 1973).

Klenow, Peter J., "Learning Curves and the Cyclical Behavior of Manufacturing Industries," Review of Economic Dynamics 1 (1998), $531-550$.

Koellinger, Philipp, "Why Are Some Entrepreneurs More Innovative Than Others?" Small Business Economics 31 (2008), 21-37.

Koellinger, Philipp, and Maria Minniti, "Unemployment Benefits Crowd Out Entrepreneurial Activity," Economics Letters 103 (2009), 9698.

Koellinger, Philipp, Maria Minniti, and Christian Schade, “"I Think I Can, I Think, I Can": Overconfidence and Entrepreneurial Behavior," Journal of Economic Psychology 28 (2007), 502-527.

Koellinger, Philipp, and Roy Thurik, "Entrepreneurship and the Business Cycle," Tinbergen Institute discussion paper no. 09-032/3 (2009; updated March 2011).

Kydland, Finn E., and Edward Prescott, "Business Cycles: Real Facts and a Monetary Myth," Federal Reserve Bank of Minneapolis Quarterly Review 14 (1990), 3-18.

Leamer, Edward D., "Homes and Cars: Why Are the Cycles in Homes and Consumer Goods So Similar?" B.E. Journal of Economic Analysis and Policy 9 (2009), Article 5.
Lucas, Robert E., "On the Size Distribution of Business Firms," Bell Journal of Economics 9 (1978), 508-523.

Lütkepohl, Helmut, New Introduction to Multiple Time Series Analysis, 2nd ed. (New York: Springer, 2007).

Lütkepohl, Helmut, and Markus Krätzig, Applied Time Series Econometrics (Cambridge: Cambridge University Press, 2004).

Malchow-Møller, Nikolaj, Bertel Schjerning, and Anders Sørensen, "Entrepreneurship, Job Creation, and Wage Growth," CAM working paper no. 2009-01 (2009). http://www.econ.ku.dk/CAM/.

Mills, David D., and Laurence Schumann, "Industry Structure with Fluctuating Demand," American Economic Review 75 (1985), 758767.

Moskovitz, Tobias J., and Annette Vissing-Jørgensen, "The Returns to Entrepreneurial Investment: A Private Equity Premium Puzzle?" American Economic Review 92 (2002), 745-778.

Nooteboom, Bart, "A Mark-Up Model of Retail Margins," Applied Economics 17 (1985), 647-667.

Nooteboom, Bart, and A. Roy Thurik, "Retail Margins during Recession and Growth," Economics Letters 17 (1985), 281-284.

Nordhaus, William D., Alberto Alesina, and Charles L. Schultze, "Alternative Approaches to the Political Business Cycle," Brookings Papers on Economic Activity 2 (1989), 1-68.

OECD, Perspectives on Global Development 2010 (Paris: OECD, 2010).

Oxenfeldt, Alfred R., New Firms and Free Enterprise (Washington DC: American Council on Public Affairs, 1943).

Parker, Simon C., The Economics of Entrepreneurship, (Cambridge: Cambridge University Press, 2009).

Payne, John W., Dan. J. Laughhunn, and Roy Crum, "Aspiration Level Effects in Risky Behavior," Management Science 27 (1981), 953958.

Pesaran, Hashem, and Ron Smith, "Estimating Long-Run Relationships from Dynamic Heterogeneous Panels," Journal of Econometrics 68 (1995), 79-113.

Rampini, Adriano, "Entrepreneurial Activity, Risk, and the Business Cycle," Journal of Monetary Economics 51 (2004), 555-573.

Ravn, Morten O., and Harald Uhlig, "On Adjusting the Hodrick-Prescott Filter for the Frequency of Observations," this REvIEw 84 (2002), 371-376.

Reynolds, Paul, Niels Bosma, Erkoo Autio, Steve Hunt, Natalie de Bono, Isabel Servais, Paloma Lopez-Garcia, and Nancy Chin, "Global Entrepreneurship Monitor: Data Collection Design and Implementation 1998-2003," Small Business Economics 24 (2005), 205-231.

Schaffner, Julie A., "Rising Incomes and the Shift from Self-Employment to Firm-Based Production," Economics Letters 41 (1993), 435-440.

Schmitz, James A., "Imitation, Entrepreneurship, and Long-Run Growth," Journal of Political Economv 97 (1989), 721-739.

Schumpeter, Jospeh A., The Theory of Economic Development (Cambridge, MA: Harvard University Press, 1934).

Schwarz, Gideon E., "Estimating the Dimension of a Model," Annals of Statistics 6 (1978), 461-464.

Shah, Sonali K., and Mary Tripsas, "The Accidental Entrepreneur: The Emergent and Collective Process of User Entrepreneurship," Strategic Entrepreneurship Journal 1 (2007), 123-140.

Shane, Scott, A General Theory of Entrepreneurship: The IndividualOpportunity Nexus (Northampton, MA: Edward Elgar, 2003).

Sims, Christopher A., "Macroeconomics and Reality," Econometrica 48 (1980), 1-48.

Storey, David J., and Andrew M. Jones, "New Firm Formation: A Labor Market Approach to Industrial Entry," Scottish Journal of Political Economy 34 (1987), 37-51.

Thurik, A. Roy, Martin A. Carree, André van Stel, and David Audretsch, "Does Self Employment Reduce Unemployment?" Journal of Business Venturing 23 (2008), 673-686.

Tripsas, Mary, "Customer Preference Discontinuities: A Trigger for Radical Technological change," Managerial and Decision Economics 29 (2008), 79-97.

Tversky, Amos, and Daniel Kahneman, "Advances in Prospect Theory: Cumulative Representation of Uncertainty," Journal of Risk and Uncertainty 5 (1992), 297-323.

Tversky, Amos, and Peter Wakker, "Risk Attitudes and Decision Weights," Econometrica 63 (1995), 1255-1280.

van der Zwan, Peter, A. Roy Thurik, and Isabel Grilo, "The Entrepreneurial Ladder and Its Determinants," Applied Economics 42 (2010), 2183-2191. 
van Stel, André, "COMPENDIA: Harmonizing Business Ownership Data across Countries and over Time," International Entrepreneurship and Management Journal 1 (2005), 105-123.

von Hippel, Eric, "Lead Users: A Source of Novel Product Concepts," Management Science 32 (1986), 791-805.

The Sources of Innovation (New York: Oxford University Press, 1988).
Wehrung, Donald A., "Risk Taking over Gains and Losses: A Study of Oil Executives," Annals of Operations Research 19 (1989), 115139.

Wennekers, Sander, and A. Roy Thurik, "Linking Entrepreneurship and Economic Growth,” Small Business Economics 13 (1999), 27-55.

Yorukoglu, Mehmet, "The Information Technology Productivity Paradox," Review of Economic Dvnamics 1 (1998), 551-592. 